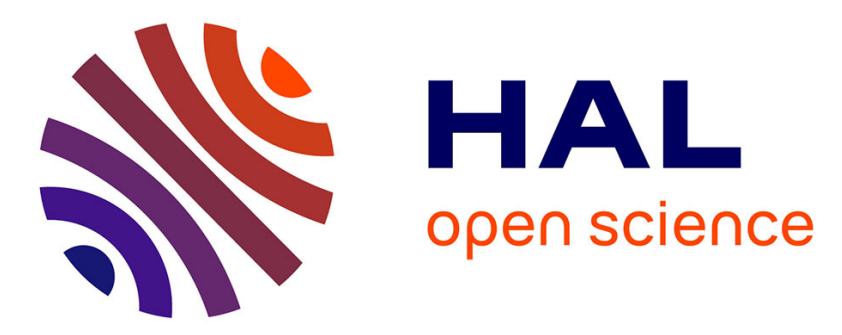

\title{
Response of Swiss forests to management and climate change in the last 60 years
}

Meinrad Küchler, Helen Küchler, Angéline Bedolla, Thomas Wohlgemuth

\section{To cite this version:}

Meinrad Küchler, Helen Küchler, Angéline Bedolla, Thomas Wohlgemuth. Response of Swiss forests to management and climate change in the last 60 years. Annals of Forest Science, 2015, 72 (3), pp.311-320. 10.1007/s13595-014-0409-x . hal-01284177

\section{HAL Id: hal-01284177 \\ https://hal.science/hal-01284177}

Submitted on 7 Mar 2016

HAL is a multi-disciplinary open access archive for the deposit and dissemination of scientific research documents, whether they are published or not. The documents may come from teaching and research institutions in France or abroad, or from public or private research centers.
L'archive ouverte pluridisciplinaire HAL, est destinée au dépôt et à la diffusion de documents scientifiques de niveau recherche, publiés ou non, émanant des établissements d'enseignement et de recherche français ou étrangers, des laboratoires publics ou privés. 


\title{
Response of Swiss forests to management and climate change in the last 60 years
}

\author{
Meinrad Küchler • Helen Küchler • Angéline Bedolla • \\ Thomas Wohlgemuth
}

Received: 19 February 2014 / Accepted: 8 July 2014 / Published online: 29 July 2014

(C) INRA and Springer-Verlag France 2014

\begin{abstract}
- Context Forest vegetation is forecasted to shift upslope several hundred metres by 2100 due to climate warming. However, only a small number of detailed assessments in selected regions have confirmed a climate response on the part of forest vegetation.

- Aims This study aimed to analyse the relative contributions of temperature and other factors to range shifts in forest vegetation by comparing old and revisited relevés in Swiss forests.

- Methods In order to investigate such range shifts, we revisited 451 relevé plots in forests in all parts of Switzerland. Collected data comprise two independent samples, one dating from the 1950s (age 60 sample) on 126 plots and the other dating from the 1990s (age 15 sample) on 325 plots. We
\end{abstract}

\section{Handling Editor: Harald Bugmann}

Contribution of the co-authors Meinrad Küchler: coordinating the research project, fieldwork, data analysis and paper writing; Helen Küchler: fieldwork and paper writing; Angéline Bedolla: planning of data collection and fieldwork; Thomas Wohlgemuth: providing access to the Swiss Forest Vegetation Database, fieldwork and paper writing

Key message An analysis of plant species range shifts in Swiss forests shows that, to date, the impact of global warming has been weaker in comparison to the effects arising from forest management and land use change. Forest species in understorey vegetation, however, have shifted upslope $10 \mathrm{~m}$ per decade.

M. Küchler $(\bowtie) \cdot$ H. Küchler $\cdot$ A. Bedolla $\cdot$ T. Wohlgemuth WSL Swiss Federal Research Institute, Zürcherstrasse 111, 8903 Birmensdorf, Switzerland

e-mail: meinrad.kuechler@wsl.ch

H. Küchler

e-mail: helen.kuechler@wsl.ch

A. Bedolla

e-mail: angeline.bedolla@wsl.ch

T. Wohlgemuth

e-mail: thomas.wohlgemuth@wsl.ch defined an indicator value for elevation to estimate the upslope and downslope range shifts of forest species. The influence of different site factors on range shifts was assessed by variance partitioning using Landolt's (2010) averaged species indicator values. Vegetation changes were analysed by balancing both increasing and decreasing frequencies of plant species.

- Results Our findings show significant differences between the two survey periods, where the averaged species indicator for elevation varied greatly in both the age- 60 and the age- 15 samples. In addition, a significant upslope shift in the herbaceous forest layer (herbs and tree regeneration) of about $10 \mathrm{~m}$ per decade since the mid-twentieth century is evident. Downslope shifts were detected in the shrub/tree layer at lower elevations, which may be explained by factors other than climate warming.

- Conclusions To date, the impact of global warming on tree species composition in Swiss forests has been weaker in comparison to the effects arising from forest management and land use change. Understorey vegetation, however, shows a strong signal of upslope shift that may be explained most adequately by a combination of climate change and other factors.

Keywords Elevational shifts $\cdot$ Forest vegetation $\cdot$ Global warming $\cdot$ Indicator values $\cdot$ Species distribution $\cdot$ Variance partitioning

\section{Introduction}

Latitudinal and elevational margins of plant species occurrence indicate a close relationship to temperature (von Humboldt and Bonpland 1807; Randin et al. 2013). If a species' distribution area is assumed to be in equilibrium with climatic or more generally environmental conditions (Guisan and Zimmermann 2000), temporal changes in species distributions can be linked to environmental change or, more 
specifically, to climate change if related variables clearly account for such changes (Walther et al. 2002; Lenoir et al. 2008). To detect temporal changes in plant species distribution, information on geo-referenced species occurrence at different times are needed. Ideally, locations of earlier vegetation survey studies serve as a first temporal reference, and these locations are then revisited for a second assessment at a recent date (e.g. Walther and Grundmann 2001). Since vegetation studies usually lack measurements of site conditions, species indicator values have often been used to both describe and interpret vegetation changes across spatial or temporal gradients (Diekmann 2003). Central European plant species have been assigned a set of indicator values expressing the average niches along environmental gradients such as light, temperature, continentality, nutrients, soil moisture and $\mathrm{pH}$ (Ellenberg 1974). For Switzerland, Landolt (1977, 2010) adapted these values to the broader range of site conditions present in the country and added indicators for humus content and soil aeration. Landolt's indicator values have frequently been used in comparative vegetation studies (e.g. Dzwonko 2001; Güsewell et al. 2012). Most often, the indicator values of individual species listed in vegetation relevés along an ecological gradient of interest are averaged, and the average value then is used to indicate the environmental conditions expressed by species composition (Schaffers and Sýkora 2000).

Statistical models have frequently been used in recent decades to describe individual species' spatial distributions (Guisan and Zimmermann 2000; Thuiller et al. 2005) and ecological ranges (Brzeziecki et al. 1993; Araújo and Guisan 2006; Zimmermann et al. 2010), as well as to predict potential future distributions of species or vegetation communities under various climate change scenarios (e.g. Brzeziecki et al. 1995; Bolliger et al. 2000; Theurillat and Guisan 2001; Dormann 2007; Hanewinkel et al. 2013). Regarding large scales, species distribution projections using both current and future climate scenarios generally yield plausible results (Walther 2010). In contrast, on a regional scale, i.e. at the level of individual European countries or provinces, the actual state of forest species occurrence may considerably differ from what is projected by models (Lenoir et al. 2010).

Discrepancies between projected or expected and actually observed changes in plant species distribution may emerge from correlations or interactions between variables used in the models. In particular, assessing the responses of plant species or communities to climate warming raises the question of whether, and to what extent, an observed or projected shift is actually caused by increased temperature or to what extent it may be explained by other factors that correlate with temperature. For instance, the nutrient supply in Swiss grassland soils is, according to several sets of vegetation records, higher in the lowlands than in the mountains (Güsewell et al. 2012). While this suggests that the nutrient supply is correlated with temperature, the actual cause is more intensive manuring and nutrient input from densely populated regions in the lowlands. Similarly, data from the Swiss National Forest Inventory (Brändli 2010) indicate a strong negative correlation between management intensity and elevation and consequently temperature. However, management intensity depends on various abiotic site factors that may be correlated with temperature and therefore responses of species to climate are difficult to disentangle from responses to land use (Gimmi et al. 2010). In France, Bertrand et al. (2011) observed that the response of forest vegetation to climate warming in lowland areas is smaller than in mountain areas. They attribute this discrepancy to human land use, which tends to disturb ecological niches more frequently and intensively in the lowlands. Analyses of fossil remnants have shown that, already several thousand years ago, human impact more than climate change has altered tree species occurrence at the tree line (Gobet et al. 2010).

Applying the species indicator approach to evaluate climate change-induced elevational shifts of species or communities and community occurrences requires a reconsideration of the indicator values assigned to single species, leading us to consider two questions: (1) To what extent do these indicator values describe the responses of species to temperature? (2) To what extent do the responses refer to other site factors that depend on elevation and that are consequently correlated with temperature? All of Landolt's indicator values are assigned to the same roughly 3,000 plant species in Switzerland. Therefore, the indicator values statistically depend on each other. In order to account for these dependencies, we applied a combined evaluation of several indicator values.

In our study, we assessed the response of forest vegetation to changing site factors by using two sets of repeated vegetation relevés recorded across Switzerland and addressed the following questions:

- How much forest plant species elevation shift (in metres) has occurred in Switzerland during the last 60 years (1950-2011; 1995-2010)?

- To what degree did temperature account for elevational shifts in comparison with other factors over the study period?

- Were elevational range shifts in species' occurrences caused by the increase or decrease of species' frequencies over the study period?

\section{Materials and methods}

\subsection{Study area}

The study area extends over the forested territory (approx. $\left.12,800 \mathrm{~km}^{2}\right)$ in Switzerland $\left(41,285 \mathrm{~km}^{2}\right)$ with a strong elevational gradient ranging from 190 to $2,400 \mathrm{~m}$ a.s.l. 
Climatic conditions include a moist oceanic climate north of the Alps (e.g. in Zürich, $426 \mathrm{~m}$ a.s.1.: $8.5^{\circ} \mathrm{C} ; 1,031 \mathrm{~mm}$; all climate data: MeteoSwiss (C) 1961-1990), dry and continental-like conditions in the Central Alps (e.g. in Sion, $482 \mathrm{~m}$ a.s.1.: $9.2^{\circ} \mathrm{C}, 598 \mathrm{~mm}$ ) and Insubrian, i.e. a subtropical climate in the southern part of Switzerland (e.g. in Magadino, $203 \mathrm{~m}$ a.s.1.: $10.5^{\circ} \mathrm{C}, 1,772 \mathrm{~mm}$ ). The major climatic differences translate into pronounced elevational gradients, with more precipitation at higher elevations and an average temperature lapse rate of $0.5^{\circ} \mathrm{C} 100 \mathrm{~m}^{-1}$, which leads to a characteristic elevational zonation of vegetation (Zimmermann and Kienast 1999). Forests at lower elevations have a complex history of intensive human land use, whereas at higher elevations, forest vegetation is more natural. Today, forests cover about $31 \%$ of Switzerland, with a maximum proportion of $51 \%$ in the southern Alps and a minimum proportion of $25 \%$ on the Central Plateau (Brändli 2010).

\subsection{Data}

Vegetation plots located throughout all forests in Switzerland were revisited (Fig. 1). Geo-referenced relevés containing abundance estimations of vascular plants and bryophytes growing on the soil served as baseline data (Braun-Blanquet approach; Braun-Blanquet 1964). The study comprises two independent old data sets, one 60 years old (age-60 sample) and one 15 years old (age-15 sample). To set up the age-60 sample, a total of 126 relevés from the 1940s and 1950s were drawn from the Swiss forest vegetation database (Wohlgemuth 2012). Only relevés with reliable coordinates and continuous forest cover according to recent aerial photographs were considered for the study. To achieve an equal distribution over Switzerland, only one out of many records per quadrant of $5 \times 5 \mathrm{~km}$ was chosen. The relevés stem from different studies that aimed at describing and classifying forest vegetation types in Switzerland (Ellenberg and Klötzli 1972; herein Etter 1943 and 1947; Trepp 1947; Moor 1952, 1954 and 1958; Braun-Blanquet et al. 1954; Kuoch 1954; Lüdi unpublished; Richard unpublished), which is why area sizes of the relevés in the age- 60 sample vary. For the revisitation, we estimated the relocation accuracy of the plots to be $10 \mathrm{~m}$. We chose the exact plot location of the earlier survey and assessed relevés on areas of $200 \mathrm{~m}^{2}$.

For the age-15 sample, 325 plots were selected from the $4 \times 4-\mathrm{km}$ grid sample ( 729 circle plots $200 \mathrm{~m}^{2}$ in size) of the Swiss National Forest Inventory (Wohlgemuth et al. 2008). The selection consisted of all $8 \times 8-\mathrm{km}$ grid points and of additional plots chosen either randomly or selectively from the rest of the $4 \times 4-\mathrm{km}$ grid points, thus ensuring an equal distribution of regions and elevations in Switzerland. Since all Swiss National Forest Inventory sample plots are permanently marked, and the plot coordinates are precise.

Plots from both the age- 60 and the age- 15 samples were revisited between 2008 and 2011, providing a second assessment of vegetation on circle plots which were $200 \mathrm{~m}^{2}$ in size.

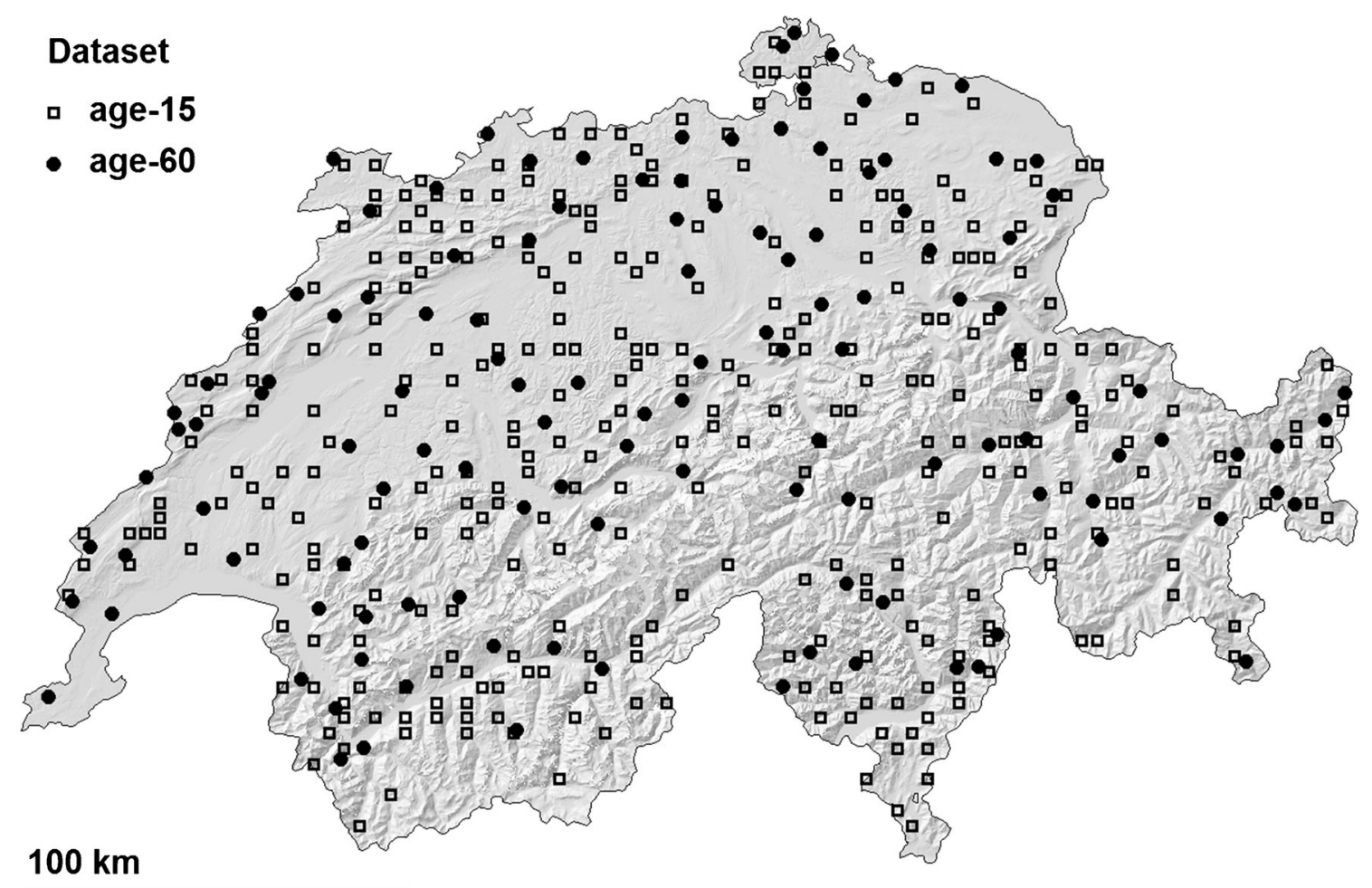

Fig. 1 Locations of the relevé plots chosen. Black circle: data from the 1950s (age-60 sample); white square: data from the 1990s (age-15 sample) 


\subsection{Indicator value for elevation}

We deduced an indicator value for elevation from a reference set of 4,089 records from the Swiss Forest Vegetation Database (Wohlgemuth 2012). To ensure representativeness regarding the wide range of site conditions, reference records were drawn as an even sample across the gradient of Landolt's indicator values for temperature $(T)$, light $(L)$, moisture $(F)$, nutrient supply $(N)$, soil reaction $(R)$, humosity $(H)$ and soil aeration $(D)$ (Landolt et al. 2010). For every species present at least five times in the reference data set, an indicator value for elevation was assigned by computing the $10 \%$-trimmed mean of the elevations of the species' occurrences. For shrub and tree species, we only took presence data regarding the herb layer into consideration. The resulting elevation indicators were then applied to the relevés from the age- 60 and age- 15 samples by averaging the corresponding species values in every relevé. No weighting of species abundance was applied. To enhance robustness and rule out extreme observations, we computed $10 \%$ trimmed means. A difference between the averaged elevation indicators of the relevés from the first and second survey indicates a change in species composition, which we interpreted as an elevational shift. The averaged indicator of a relevé denotes the elevation at which similar vegetation can be found in the reference data set. If the elevation indicator of the second (i.e. recent) survey of one plot is lower than in the first, this implies that current species composition corresponds to reference data for lower elevations in comparison to the composition from the first survey. In other words, in this case, species composition has a temporal upslope shift. The amount of the shift is, however, underestimated because the range of the averaged elevation indicator values is smaller than the elevation range of the reference plots. Therefore, we compared the interquartile range of the averaged elevation indicators with the interquartile range of the actual elevations of the plots. We found that the elevational range indicated by the indicators was too small by a factor of 2.2 (Fig. 2). The differences between the elevation indicators from the first and the second surveys were thus multiplied by this factor.

\subsection{Assessing the influence of different site factors using variance partitioning}

We partitioned the variance of the averaged elevation indicator values of the relevés (response variable) to identify shared and independent components (predictor variables) through linear regression analyses. Partitioning referred to two groups of predictor variables: Landolt's indicator value for temperature $T$ (group 1) and the remaining Landolt's indicator values $(L, F$, $N, R, H, D$; group 2). Goodness-of-fit was expressed as adjusted $R^{2}$. In a similar way, we partitioned the variance of the changes in the elevation indicator value (response) into changes in temperature indicator value (dT; predictor group 1) and in the remaining indicator values $(\mathrm{dL}, \mathrm{dF}, \mathrm{dN}, \mathrm{dR}, \mathrm{dH}, \mathrm{dD}$; predictor group 2).

\subsection{Increase or decrease in frequencies}

An upslope range shift of a species' distribution can be caused by either an increased species frequency which occurs when colonising higher elevations or a decreased frequency at lower elevations due to competitive exclusion. Analogously, a shift towards denser forest stands is indicated by fewer lightdemanding and more abundant shade-tolerant species. Such changes between the relevés from the first and the second survey are indicated by differences between the number and proportions of species with high or low values in particular (Landolt et al. 2010).

To reduce data, we expressed tree species composition in frequencies of conifers and broadleaf species (e.g. Brändli 2010). Changes between the two surveys were analysed in the same way as described for changes in indicator values.

\subsection{Canopy layers and elevational belts}

The data were analysed separately for shrub/tree and herb layers and for three elevational belts. The shrub/tree layer consists of woody plants, i.e. shrubs and trees taller than $50 \mathrm{~cm}$ (based on the Landolt et al. (2010) classification). The three elevational belts were delimited by dividing the data into three roughly similar elevational categories (low, mid and high elevation) with equal numbers of plots: 350-749, $750-1,199$ and 1,200-2,300 $\mathrm{m}$ a.s.l. for the age-60 sample and $290-749,750-1,249$ and $1,250-2,190 \mathrm{~m}$ a.s.l. for the age-15 sample.

Data sets were analysed by using VEGEDAZ (Küchler 2014) and R version 3.0.0 (R Development Core Team 2013).

\section{Results}

\subsection{Averaged indicator values for elevation}

Changes in averaged indicator values for elevation differed with respect to both the three elevational belts and the shrub/ tree and herb layers (Fig. 3). The age-60 sample showed marked uphill shifts in the herb layer for all three elevational belts $(107,44$ and $58 \mathrm{~m}$ at low, mid and high elevations, respectively; averaging $65 \mathrm{~m}$ ) and a downslope shift in the shrub/tree layer at low elevations (Fig. 3a). The age-15 sample showed a significant upslope shift in the herb layer only at mid-elevations and a significant downslope shift in the shrub/ tree layer at high elevations (Fig. 3b). 
Fig. 2 Observed elevations and averaged indicator values for elevation of relevés in the age-15 plots. a Scatterplot. b Boxplot; the boxes show the interquartile ranges a)

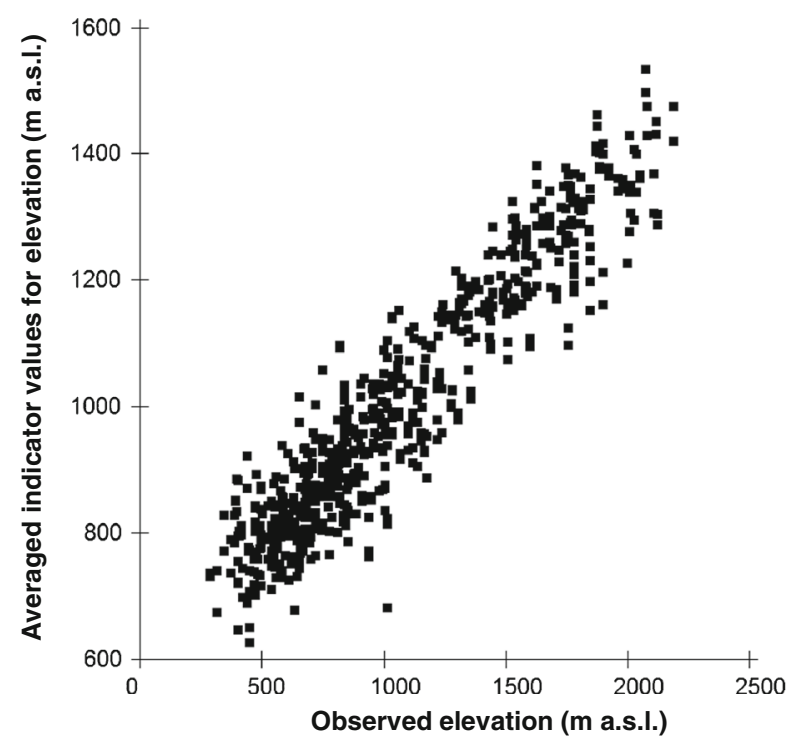

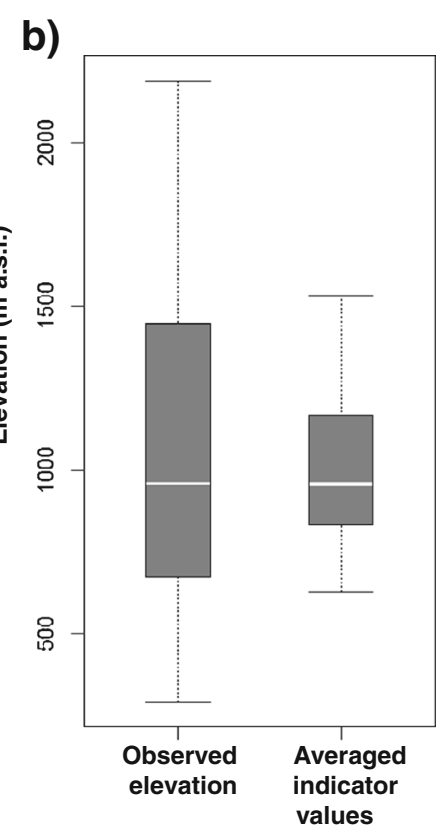

3.2 Variance partitioning of the elevation indicator value

The full model explained $91 \%$ of total variance in the age-60 sample and $93 \%$ in the age- 15 sample (Table 1). The temperature indicator value explained independently $34 \%$ of total variance in the age- 60 sample and $23 \%$ in the age- 15 sample. The remaining indicator values $(L, F, N, R, H, D)$ explained 1 and $2 \%$ of the variance uniquely. The shared variance of both groups accounted for a large part of total variance (56\% in the age-60 sample and $67 \%$ in the age-15 sample), which suggests strong collinearity.

\subsection{Variance partitioning of elevational shifts}

To assess the extent to which forest plant species responded to temperature change as reflected in the elevational shift, variance of changes in the elevation indicator value was partitioned to separate changes in the temperature indicator value (group 1) from changes in the remaining indicator values (group 2; Table 2). Species in the herb layer at mid elevations (both samples) and high elevations in the age-60 sample exhibited a significant directed upslope shift (Fig. 3). The variance of this shift is explained, to a considerable
Fig. 3 Changes in averaged indicator value for elevation (10\% trimmed means) between the relevés from old and recent surveys from the a age- 60 and $\mathbf{b}$ age-15 sample. Significance levels of signed-rank test, ${ }^{*} p<0.05,{ }^{* *} p<0.01,{ }^{* * *} p<0.001$

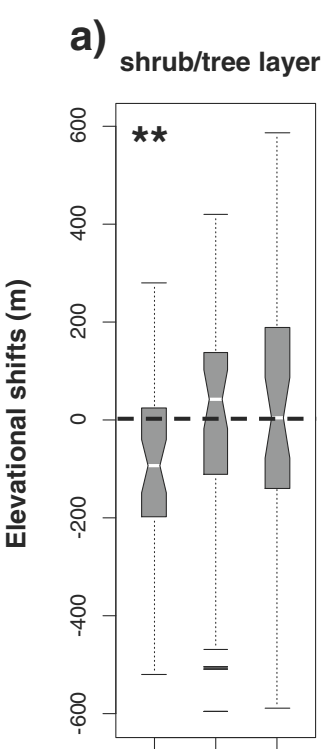

Elevation low mid high

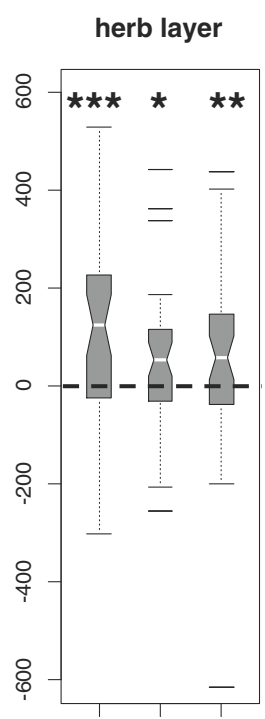

low mid high b)

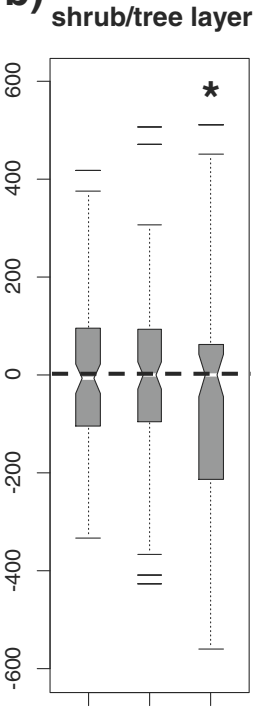

Elevation low mid high

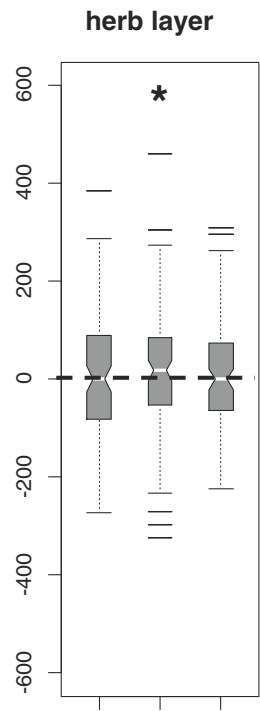

low mid high

1950 - 2011 (age-60) 
Table 1 Variance partitioning of the averaged indicator values for elevation (adjusted $R^{2}$, in \%) between the temperature indicator value $T$ and the remaining indicator values $(L, F, N, R, H, D)$

\begin{tabular}{lll}
\hline & Age-60 data & Age-15 data \\
\hline Temperature indicator value $T$ & 90 & 91 \\
$L, F, N, R, H, D$ indicator values & 57 & 69 \\
Unique to $T$ & 34 & 23 \\
Unique to $L, F, N, R, H, D$ & 1 & 2 \\
Common & 56 & 67 \\
Full model & 91 & 93 \\
Unexplained & 9 & 7 \\
\hline
\end{tabular}

extent, uniquely by the temperature value change (dT). The marked upslope shift in the herb layer at low elevations in the age-60 sample $(107 \mathrm{~m})$ is predominantly explained by the change in factors other than temperature $(52 \%$ of the variance is explained independently by $\mathrm{dL}, \mathrm{dF}, \mathrm{dN}, \mathrm{dR}, \mathrm{dH}, \mathrm{dD}$ ). In the shrub/tree layer, the change in the temperature indicator value (dT) explained $29 \%$ of the variance in the age- 60 sample at low elevations and $17 \%$ in the age- 15 sample at high elevations, whereas the remaining indicator values $(\mathrm{dL}, \mathrm{dF}, \mathrm{dN}, \mathrm{dR}$, $\mathrm{dH}, \mathrm{dD}$ ) explained 12 and $18 \%$ uniquely. A negative commonality $(-5 \%)$ was found for the shrub/tree layer at low elevations, indicating that the effects of temperature and other factors tended to compensate each other.

\subsection{Shifts in the frequencies of species}

Both increases and decreases in the frequencies of species along the elevational gradient can lead to shifts in individual species' optima. In the age-60 sample, the number of species per relevé decreased at low elevations and increased at high elevations over the time span of 60 years. Thus, at lower elevations, the mean temperature indicator value for species in the woody layer is reflected by a reduction of predominantly thermophile shrub and tree species (Fig. 4a). In contrast, the mean temperature value of species in the herb layer at low elevations mainly corresponds to the decreased frequency of species that have adapted to low temperatures (Fig. 4b). At higher elevations, the appearance of thermophiles was more marked than the increase of cold-resistant species (Fig. 4b). In both woody and herb layers, the mean nutrient indicator values at low elevations is mainly in line with the reduction in species with low nutrient requirements (Fig. 4c, d). In contrast, species with predominantly higher nutrient requirements appeared in the herb layer at higher elevations (Fig. 4d). The statistically highly significant decrease in the mean light indicator values in both layers at low elevations clearly corresponds with the decrease in light-demanding species and the increase in shade-tolerant species (Fig. 4e, f).

The proportion of conifer species increased in the wood/shrub layer at low elevations due to the increase in conifers and the decrease in broadleaf species (Fig. 5a). At higher elevations, the lowered proportion of conifers in the herb layer corresponds mainly to the appearance of broadleaf species (Fig. 5b).

\section{Discussion}

4.1 Elevational shifts of plant species in Swiss forests

Differences between current and earlier forest vegetation in Switzerland as measured by averaged indicators for elevation vary considerably in both the age- 60 and the age- 15 samples

Table 2 Variance partitioning (adjusted $R^{2}$; in \%) of change in averaged indicator values for elevation between change in temperature indicator value $(\mathrm{dT})$ and change in the remaining indicator values $(\mathrm{dL}, \mathrm{dF}, \mathrm{dN}, \mathrm{dR}, \mathrm{dH}, \mathrm{dD})$

\begin{tabular}{|c|c|c|c|c|c|c|}
\hline Elevational belt & \multicolumn{2}{|l|}{ Low elevation } & \multicolumn{2}{|l|}{ Mid elevation } & \multicolumn{2}{|l|}{ High elevation } \\
\hline \multicolumn{7}{|l|}{ Age-60 sample (1950-2011) } \\
\hline Elevational range in $\mathrm{m}$ & $350-750$ & & $750-1,200$ & & $1,200-2,300$ & \\
\hline Canopy layer & Shrubs/trees & Herbs & Shrubs/trees & Herbs & Shrubs/trees & Herbs \\
\hline Unique to $\mathrm{dT}$ & 29 & 20 & 29 & 37 & 18 & 42 \\
\hline Unique to $\mathrm{dL}, \mathrm{dF}, \mathrm{dN}, \mathrm{dR}, \mathrm{dH}, \mathrm{dD}$ & 12 & 52 & 5 & 10 & 8 & 0 \\
\hline Shared & -5 & -1 & 29 & 8 & 35 & 17 \\
\hline \multicolumn{7}{|l|}{ Age-15 sample (1995-2010) } \\
\hline Elevational range in $\mathrm{m}$ & $290-750$ & & $750-1,250$ & & $1,250-2,190$ & \\
\hline Canopy layer & Shrubs/trees & Herbs & Shrubs/trees & Herbs & Shrubs/trees & Herbs \\
\hline Unique to $\mathrm{dT}$ & 37 & 32 & 26 & 31 & 17 & 30 \\
\hline Unique to $\mathrm{dL}, \mathrm{dF}, \mathrm{dN}, \mathrm{dR}, \mathrm{dH}, \mathrm{dD}$ & 8 & 10 & 1 & 1 & 18 & 5 \\
\hline Shared & 13 & 7 & 10 & 1 & 7 & 10 \\
\hline
\end{tabular}


Fig. 4 Age-60 sample. Mean number of species per relevé in classes of indicator values (ranging from 1 to $5 ; X$ for species lacking an indicator value assignment), for shrub/tree and herb layers and for elevational belts (low, mid, high).

Significance levels for an increase $(+)$ or a decrease $(-)$ in averaged indicator values between surveys (signed-rank test): $* p<0.05$, $* * p<0.01, * * * p<0.001$ a) Temperature (shrub/tree layer)

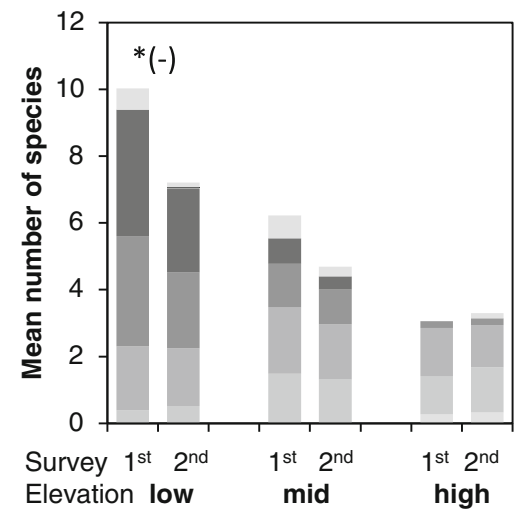

C) Nutrients (shrub/tree layer)

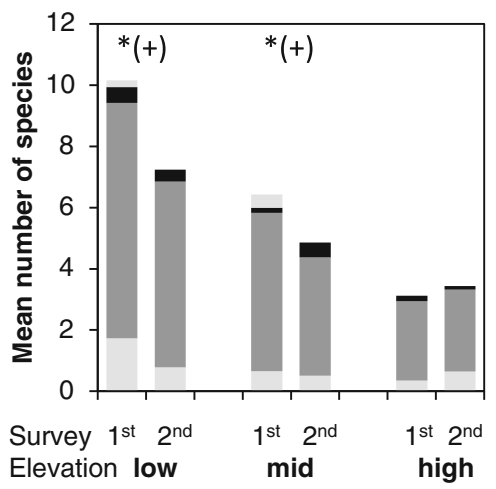

e) Light (shrub/tree layer)

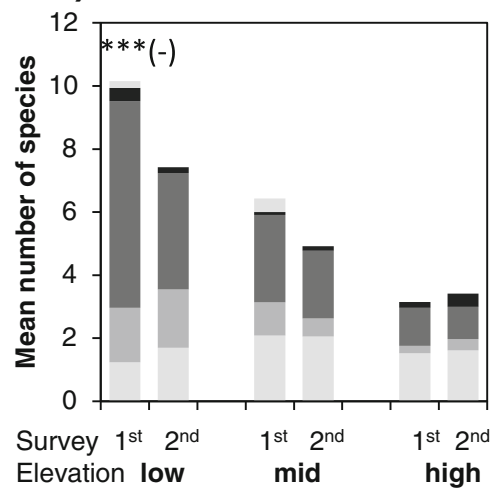

b) Temperature (herb layer)

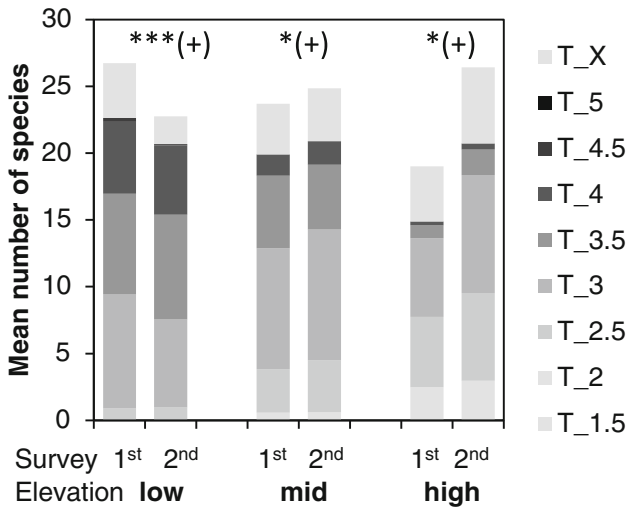

d) Nutrients (herb layer)

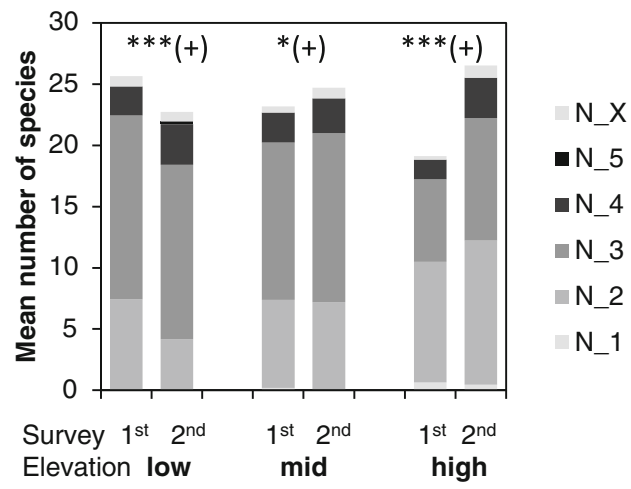

f) Light (herb layer)

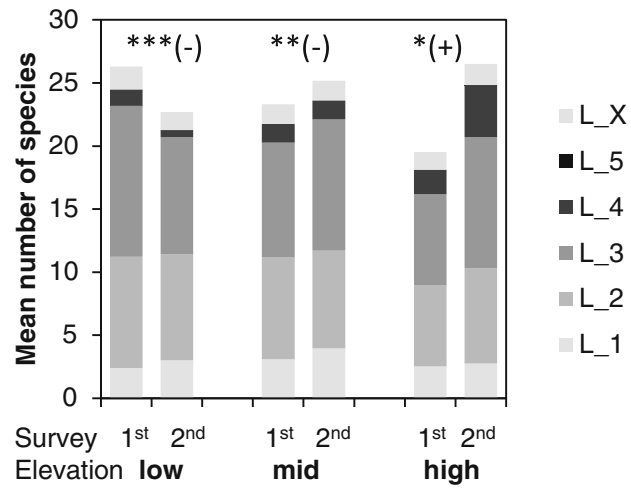

(Fig. 3). Some significant overall shifts are, however, apparent. According to our results, changes in the herbaceous layer correspond to an average upslope shift of $65 \mathrm{~m}$, which corresponds to a rate of $10 \mathrm{~m}$ per decade since the middle of the twentieth century. In the same time period, the mean yearly temperature has risen by at least $0.15{ }^{\circ} \mathrm{C}$ per decade (Perroud and Bader 2013). This upslope shift rate is about three to five times smaller than predicted by earlier species and vegetation distribution projections (Brzeziecki et al. 1995; Zimmermann et al. 2006). Our observations of upslope shifting are consistent with a similar study from southern France (Lenoir et al.
2008), where an upslope shift of $29 \mathrm{~m}$ per decade was detected in correspondence with a temperature rise of $0.45{ }^{\circ} \mathrm{C}$ per decade.

In contrast to the clear signal in the herbaceous layer, a general upslope range shift in the shrub/tree layer is not evident. Below $750 \mathrm{~m}$ a.s.l. (Fig. 3a), even a conspicuous downslope shift is signalled by the species' range comparisons. The clear difference between shrub/tree and herb layers may, to some extent, be explained by the delayed response of long-lived species to climate change (Lenoir and Svenning 2013). On the other hand, the contrasting succession signals of 
Fig. 5 Age-60 sample. Mean number of conifer and broadleaf species per relevé, for shrub/tree and herb layers and for elevational belts (low, mid, high) Significance levels for an increase $(+)$ or a decrease $(-)$ in the proportion of conifer species between surveys (signed-rank test): ${ }^{*} p<0.05, * * p<0.01$, $* * * p<0.001$
Conifer and broadleaf species

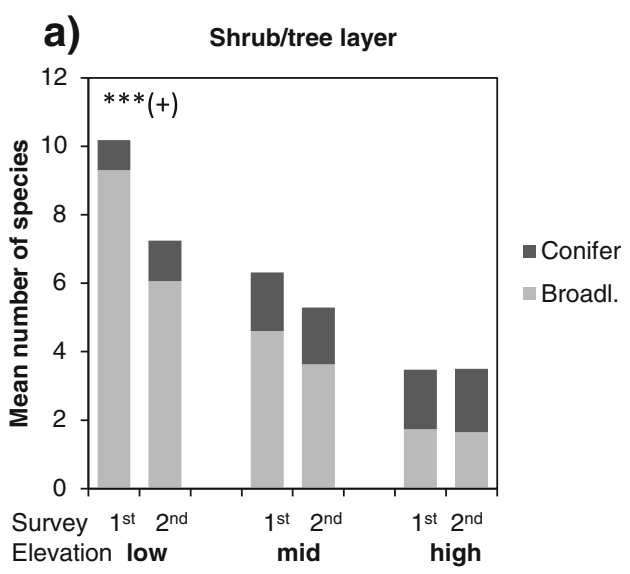

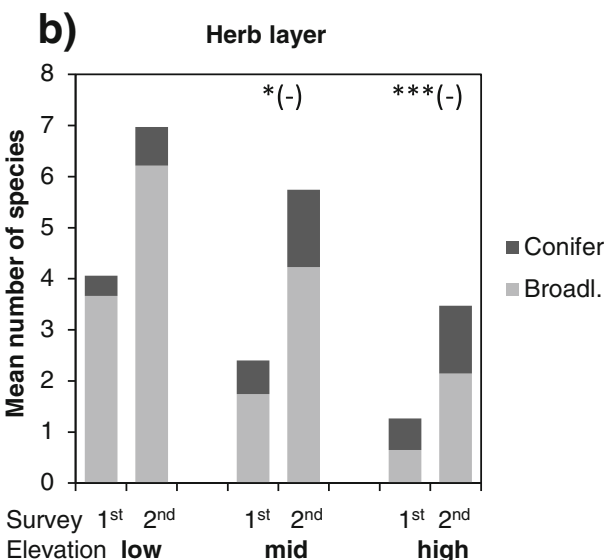

herbaceous and woody vegetation layers may also indicate that species composition in forests is affected by strong nonclimatic factors, which, in the case of shrubs and trees, override the response to climate change.

\subsection{Climate and non-climate factors as drivers}

Statistically, elevational shifts were, to a large extent, explained by changes in Landolt's species indicator value for temperature (Table 2). However, changes in the indicator values for other site factors also explained a considerable part of the variance. Given the collinearity of Landolt's species indicators (Table 1) and the fact that Landolt's temperature value relies mainly on the elevational distributions of species (Landolt et al. 2010), a conservative interpretation is necessary. We believe that the explained variances shared between species indicator values for temperature and other indicator values (Table 2) is accounted for by factors other than temperature. We can only accept variance that is uniquely explained by the temperature indicator value as a valid indicator of a response to warming. This implies that the effects of warming may be hidden by opposing trends and possibly remain undetected. For instance, a continuously closing canopy results in more shade which may lead to a cooler microclimate (von Arx et al. 2012) and thus counteracts a response to a warming macroclimate. The results of the variance partitioning analysis suggest that climate change caused at least some of the significant upslope shifts in the herb layer at middle elevations (age-60 and age-15 samples) and at high elevations (age-60 sample). In contrast, factors other than temperature increases are likely to play a role in the marked upslope shift of herb vegetation at low elevations $(+107 \mathrm{~m}$, Table 2$)$ in the age-60 sample.

\subsection{Increases and decreases in the frequencies of species}

In the age-60 sample, forest vegetation at low elevations changed mainly with both the decrease of light-demanding $(L$ values 4,5$)$ and stress-tolerant species $(N$ values 1,2 ; Fig. 4). This result is consistent with Brändli (2010), who reports that lowland forests have generally become denser due to lower management intensity during recent decades. A discrepancy between temperature indicator values in the herb layer (increase) and in the shrub/tree layer (decrease) can be partly explained as the result of the plantation of spruce during the middle of the twentieth century (Bürgi and Schuler 2003). This management measure is visible in the age- 60 data as an increase in conifers (Fig. 5) and as a downslope shift of shrub/ tree composition at low elevations (Fig. 3).

In forests at higher elevations, both species with a high demand for nutrients, light and warmth in the herb layer and broadleaf tree species increased in numbers. In particular, an increase in species of tall herb communities and in nonconiferous species can be interpreted as the result of the abandonment of wood pastures and the direct and indirect effects of wind disturbances that created huge open areas in the Swiss Pre-Alps. An invasion of broadleaf species at mid and high elevations has also been reported in the Pyrenees (Hernández et al. 2013). Disturbance as a potential mechanism to explain downslope range shifts during periods of climate change has recently been noted by Lenoir et al. (2010). In addition, species may also expand or reduce their range margins due to legacy effects related to former management that has been altered in recent decades.

\section{Conclusions}

The results of this study indicate that the impact of contemporary global warming on tree species composition in Swiss 
forests has been much weaker than that of management and other disturbance effects. Nevertheless, understorey vegetation shows a considerable upward shift, part of which can probably best be explained by global warming. Forest vegetation has sometimes been modified in unexpected ways, in particular as a reaction to former and actual land use. Evidence of current and future changes in forest vegetation due to climate warming can only be found through long-term monitoring of vegetation. We demonstrate that tree, shrub and herb canopies must be studied separately in order to comprehensively understand the effects of climate change and to disentangle climate change from other influencing factors such as succession and management. In particular, the response of trees and shrubs to climate change seems to have been either delayed or strongly affected by management.

Global temperature is a slowly changing factor that affects forest vegetation only very subtly. In contrast, windthrow, fire, disease and forest management result in clear and abrupt forest changes. Many of these factors interact, which makes forecasting future forest composition rather speculative. One strong indication of our study, however, is that disturbance and management influence woody vegetation more than contemporary and future warming. Hence, management by objectives will be one key approach to ensure that forests can adapt appropriately to a changing environment.

Acknowledgments We are grateful to Silvia Dingwall and Curtis Gautschi for revising the English text. We also thank the editors and two anonymous reviewers for their constructive comments.

Funding Funding for this study was provided by the Swiss National Forest Inventory and by the "Forests and Climate Change" research programme, a joint initiative of the Federal Office for the Environment, Bern, and of the Swiss Federal Institute for Forest, Snow and Landscape Research, Birmensdorf.

\section{References}

Araújo MB, Guisan A (2006) Five (or so) challenges for species distribution modelling. J Biogeogr 33:1677-1688. doi:10.1111/j.13652699.2006.01584.x

Bertrand R, Lenoir J, Piedallu C, Riofrio-Dillon G, de Ruffray P, Vidal C, Pierrat J-C, Gégout J-C (2011) Changes in plant community composition lag behind climate warming in lowland forests. Nature 479: 517-520. doi:10.1038/nature10548

Bolliger J, Kienast F, Zimmermann NE (2000) Risks of global warming on montane and subalpine forests in Switzerland - a modeling study. Reg Envir Change 1:99-111. doi:10.1007/s101130000018

Brändli U-B (2010) Schweizerisches Landesforstinventar. Ergebnisse der dritten Erhebung 2004-2006, Birmensdorf, Eidg Forschungsanst Wald Schnee Landschaft WSL. Bern, Bundesamt für Umwelt, BAFU

Braun-Blanquet J (1964) Pflanzensoziologie. Springer, Wien

Brzeziecki B, Kienast F, Wildi O (1993) A simulated map of the potential natural forest vegetation of Switzerland. J Veg Sci 4:499-508
Brzeziecki B, Kienast F, Wildi O (1995) Modelling potential impacts of climate change on the spatial distribution of zonal forest communities in Switzerland. J Veg Sci 6:257-268

Bürgi M, Schuler A (2003) Driving forces of forest management - an analysis of regeneration practices in the forests of the Swiss Central Plateau during the 19th and 20th century. For Ecol Manag 176:173-183

Diekmann M (2003) Species indicator values as an important tool in applied plant ecology—a review. Basic Appl Ecol 4:493-506. doi: 10.1078/1439-1791-00185

Dormann CF (2007) Promising the future? Global change projections of species distributions. Basic Appl Ecol 8:387-397. doi: http:// dx.doi.org/10.1016/j.baae.2006.11.001

Dzwonko Z (2001) Assessment of light and soil conditions in ancient and recent woodlands by Ellenberg indicator values. J Appl Ecol 38: 942-951. doi:10.1046/j.1365-2664.2001.00649.x

Ellenberg H (1974) Indicator values of vascular plants in central Europe. Scripta Geobotanica 9:1-97

Ellenberg H, Klötzli F (1972) Waldgesellschaften und Waldstandorte der Schweiz. Mitt Schweiz Anst Forstl Versuchsw 48:388-930

Gimmi U, Wohlgemuth T, Rigling A, Hoffmann CW, Buergi M (2010) Land-use and climate change effects in forest compositional trajectories in a dry Central-Alpine valley. Ann For Sci 67. doi: 70110. $1051 /$ forest/2010026

Gobet E, Vescovi E, Tinner W (2010) A paleoecological contribution to assess the natural vegetation of Switzerland. Bot Helv 120:105-115. doi:10.1007/s00035-010-0080-2

Guisan A, Zimmermann NE (2000) Predictive habitat distribution models in ecology. Ecol Model 135:147-186. doi:10.1016/s0304-3800(00) 00354-9

Güsewell S, Peter M, Birrer S (2012) Altitude modifies species richness - nutrient indicator value relationships in a country-wide survey of grassland vegetation. Ecol Indic 20:134-142. doi:10.1016/j. ecolind.2012.02.011

Hanewinkel M, Cullmann DA, Schelhaas M-J, Nabuurs G-J, Zimmermann NE (2013) Climate change may cause severe loss in the economic value of European forest land. Nature Clim Change 3: 203-207. doi:10.1038/nclimate1687

Hernández L, Cañellas I, Alberdi I, Torres I, Montes F (2013) Assessing changes in species distribution from sequential large-scale forest inventories. Ann For Sci 71:161-171. doi:10.1007/s13595-0130308-6

Küchler M (2014) Software VEGEDAZ. Programm für die Erfassung und Auswertung von Vegetationsdaten. Update 2014. Forschungseinheit Biodiversität und Naturschutzbiologie, Eidg. Forschungsanstalt WSL, Birmensdorf

Landolt E (1977) Ökologische Zeigerwerte zur Schweizer Flora. Veröff Geobot Inst ETH, Stift Rübel Zürich 64:1-208

Landolt E, Bäumler B, Erhardt A, Hegg O, Klötzli F, Lämmler W, Nobis M, Rudmann-Maurer K, Schweingruber FH, Theurillat J-P, Urmi E, Vust M, Wohlgemuth T (2010) Flora indicativa - Ökologische Zeigerwerte und biologische Kennzeichen zur Flora der Schweiz und der Alpen. Haupt, Verlag

Lenoir J, Svenning J-C (2013) Latitudinal and elevational range shifts under contemporary climate change. Encyclopedia of biodiversity (2nd ed) 4:599-611

Lenoir J, Gégout JC, Marquet PA, de Ruffray P, Brisse H (2008) A significant upward shift in plant species optimum elevation during the 20th century. Science 320:1768-1771. doi:10.1126/science.1156831

Lenoir J, Gegout J-C, Guisan A, Vittoz P, Wohlgemuth T, Zimmermann NE, Dullinger S, Pauli H, Willner W, Svenning J-C (2010) Going against the flow: potential mechanisms for unexpected downslope range shifts in a warming climate. Ecography 33:295-303. doi:10. 1111/j.1600-0587.2010.06279.x

Perroud M, Bader S (2013) Klimaänderung in der Schweiz. Indikatoren zu Ursachen, Auswirkungen, Massnahmen. In: Bern BfU (ed) Umwelt-Zustand, pp. 86 
R Development Core Team (2013) R: a language and environment for statistical computing. R Foundation for Statistical Computing, Vienna, Austria

Randin CF, Paulsen J, Vitasse Y, Kollas C, Wohlgemuth T, Zimmermann NE, Körner C (2013) Do the elevational limits of deciduous tree species match their thermal latitudinal limits? Glob Ecol Biogeogr 22:913-923. doi:10.1111/geb.12040

Schaffers AP, Sýkora KV (2000) Reliability of Ellenberg indicator values for moisture, nitrogen and soil reaction: a comparison with field measurements. J Veg Sci 11:225-244. doi:10.2307/ 3236802

Theurillat J-P, Guisan A (2001) Potential impact of climate change on vegetation in the European alps: a review. Clim Change 50:77-109. doi:10.1023/a:1010632015572

Thuiller W, Richardson DM, Pysek P, Midgley GF, Hughes GO, Rouget M (2005) Niche-based modelling as a tool for predicting the risk of alien plant invasions at a global scale. Glob Change Biol 11:2234-2250. doi:10.1111/j.1365-2486. 2005.01018.x

von Arx G, Dobbertin M, Rebetez M (2012) Spatio-temporal effects of forest canopy on understory microclimate in a long-term experiment in Switzerland. Agric For Meteorol 166:144-155. doi:10.1016/j. agrformet.2012.07.018

von Humboldt A, Bonpland A (1807) Ideen zu einer Geographie der Pflanzen nebst einem Naturgemälde der Tropenländer, F.G. Cotta, Tübingen; F. Schoell, Paris
Walther G-R (2010) Community and ecosystem responses to recent climate change. Philos T Roy Soc B 365:2019-2024. doi:10.1098/ rstb. 2010.0021

Walther G-R, Grundmann A (2001) Trends of vegetation change in colline and submontane climax forests in Switzerland. Bull Geobot Inst ETH Zürich 67:3-12

Walther G-R, Post E, Convey P, Menzel A, Parmesan C, Beebee TJC, Fromentin J-M, Hoegh-Guldberg O, Bairlein F (2002) Ecological responses to recent climate change. Nature 416:389-395

Wohlgemuth T (2012) Swiss forest vegetation database. In: Dengler J, Oldeland J, Jansen F, Chytrý M, Ewald J, Finckh M, Glöckler F, Lopez-Gonzalez G, Peet RK, Schaminée JHJ (eds) Vegetation databases for the 21st century, pp. 340-340

Wohlgemuth T, Moser B, Braendli UB, Kull P, Schuetz M (2008) Diversity of forest plant species at the community and landscape scales in Switzerland. Plant Biosyst 142:604-613. doi: Pii $90568496010.1080 / 11263500802410975$

Zimmermann NE, Kienast F (1999) Predictive mapping of alpine grasslands in Switzerland: species versus community approach. J Veg Sci 10:469-482

Zimmermann NE, Bolliger J, Gehrig-Fasel J, Guisan A, Kienast F, Lischke H, Rickebusch S, Wohlgemuth T (2006) Wo wachsen die Bäume in 100 Jahren? Wald und Klimawandel Forum Wissen 2006:63-71

Zimmermann NE, Edwards TC, Graham CH, Pearman PB, Svenning J-C (2010) New trends in species distribution modelling. Ecography 33: 985-989. doi:10.1111/j.1600-0587.2010.06953.x 